\title{
Financial Literacy: Pengetahuan, Kepercayaan Diri dan Perilaku Keuangan Mahasiswa Akuntansi
}

\author{
Gilang Puspita, Surabaya, \\ Indonesia \\ gilangpuspita16@gmail.com
}

\author{
Isnalita, Surabaya, Indonesia \\ isnalita@feb.unair.ac.id
}

ABSTRAK

The aims of this research is to examine the effect of financial knowledge and self confidence on financial behavior, the effect of self confidence on financial behavior, and the role of mediating self confidence on the relationship of financial knowledge to financial behavior. This research processed primary data using a questionnaire distributed to the student of Airlangga University. The research sample was selected using the Slovin formula at the level of confidence 5\%. The sample analyzed were 328 questionnaire. The analytical tool used is Structural Equation Modeling with the Partial Least Square approach. The results showed that financial knowledge had an effect on self-confidence, selfconfidence had an effect on financial behavior, self-confidence mediated the effect of financial knowledge on financial behavior. In addition, financial knowledge does not affect financial behavior.

Keywords : financial knowledge, self-confidence, financial behaviour, financial literacy

\section{Pendahuluan}

Tren global mengantisipasi bahwa hubungan antara individu dan sistem keuangan akan meningkat. Faktor-faktor seperti meningkatnya harapan hidup dan perubahan kemakmuran negara mendorong semakin banyak individu harus dilibatkan dalam mengambil keputusan keuangan. Keputusan seperti menabung untuk pensiun, pengeluaran untuk pendidikan dan kesehatan, atau membeli rumah, diambil dalam skenario di mana pasar keuangan lebih mudah diakses oleh konsumen, karena kemajuan teknologi utama (pengurangan biaya transaksi antara penawaran dan permintaan) dan penampilan baru jasa keuangan.

Kaum muda harus beroperasi di dunia keuangan yang semakin kompleks, khususnya mereka yang tinggal di negara maju. Mengingat kapasitas pengeluaran mereka yang menonjol, anak muda orang adalah target yang menarik, terutama untuk perbankan dan lembaga kartu kredit. Namun, mereka memiliki kemampuan terbatas dalam mengambil keputusan keuangan yang benar. Pendidikan keuangan di kalangan kaum muda dan persiapan mereka untuk pengambilan keputusan dalam kehidupan mereka di masa depan telah meningkatkan kekhawatiran pemerintah.

Mahasiswa sebagai kaum muda merupakan individu yang dekat dengan teknologi informasi dan digital, dimana mereka mampu untuk mengaplikasikan semua kegiatan dalam satu waktu dengan menggunakan tekonologi informasi yang ada. Kondisi ini membuat mahasiswa mampu untuk menyerap informasi lebih banyak guna mendukung aktivitas yang ada, akan tetapi kondisi ini menimbulkan sebuah permasalahan dimana mahasiswa dimungkinkan untuk menjadi lebih konsumtif dalam membelanjakan uang mereka. Oleh karena itu, untuk mencegah terjadinya konsumerisme yang berlebihan pada mahasiswa dibutuhkan literasi keuangan (financial literacy), sehingga mereka mampu untuk mengendalikan keuangan mereka secara bijak agar pola konsumerisme tidak menjadikan masalah bagi mahasiswa di masa depan (Lusardi \& Mitchell, 2014).

Literasi keuangan merupakan hal penting bagi individu-individu yang mengalami peningkatan aktivitas dalam lingkungan yang semakin kompleks (Atkinson \& Messy, 2012). Pemerintah di seluruh dunia tertarik untuk mencari pendekatan yang efektif untuk meningkatkan tingkat literasi keuangan penduduk mereka melalui penciptaan atau peningkatan strategi nasional untuk pendidikan keuangan dengan tujuan menawarkan kesempatan belajar di berbagai tingkat pendidikan (Atkinson \& Messy, 2012).

Literasi keuangan mencerminkan 
kemampuan individu untuk memahami informasi keuangan dan menggunakannya dengan terampil dan percaya diri (Huston, 2010), serta dipahami sebagai fenomena kompleks yang terdiri dari kombinasi pengetahuan, sikap, dan perilaku (OECD, 2012), yang cocok untuk digunakan dari pandangan multi-dimensi untuk membuat konsep dan mengoperasionalkan konstruk yang ada (Huston, 2010).

Konseptualisasi mengenai literasi keuangan meminimalisir terjadinya bias perilaku yang dapat terjadi dalam proses pengambilan keputusan keuangan individu (Schmeiser \& Seligman, 2013). Lyons (2004) mengindikasikan bahwa produk dan jasa keuangan secara inheren telah meningkat dan menjadi lebih kompleks tanpa disertai dengan pertumbuhan yang sepadan dalam tingkat literasi keuangan dalam kehidupan individu-individu modern. Dalam hal ini, sejumlah individu dengan keuangan potensial tidak memiliki pengetahuan keuangan yang relevan dengan konsep dan keterampilan yang diperlukan untuk memfasilitasi pilihan dan keputusan mereka yang paling bermanfaat untuk meningkatkan kualitas hidup dan kesejahteraan (Atkinson \& Messy, 2012; Lusardi \& Mitchell, 2014).

Oleh karena itu, dalam sebuah studi literasi keuangan, penting untuk mengevaluasi proses pengambilan keputusan individu, serta menyelidiki kemungkinan perilaku positif individu terkait dengan keuangan mereka yang dapat menghasilkan peningkatan ketahanan di saat-saat krisis (OECD, 2012). Selain itu, memahami perilaku keuangan individu dalam mendorong kesejahteraan keuangan (Huston, 2010; OECD, 2012), dan perilaku individu dalam kepuasan finansial yang lebih besar (Grable \& Joo, 2004).

Perilaku keuangan melihat pendekatan pengambilan keputusan individu, termasuk bias kognitif dan emosional. Perilaku keuangan membuat premis bahwa berbagai masalah obyektif dan subyektif mempengaruhi proses pengambilan keputusan. Perilaku keuangan membuat premis bahwa berbagai masalah obyektif dan subyektif mempengaruhi proses pengambilan keputusan. Berbagai penelitian, survei, dan studi pasar di dokumen mendokumentasikan bagaimana individu dalam kehidupan nyata membuat penilaian dan keputusan terkait dengan keputusan keuangan (Baker \& Ricciardi, 2014).

Model literasi keuangan merupakan model membentuk perilaku keuangan individu, dimana perilaku keuangan dipengaruhi oleh pengetahuan keuangan dan kepercayaan diri individu (Huston, 2010; Potrich et al., 2016). Individu yang tidak terbiasa dengan konsep pengetahuan keuangan dasar merasa sulit untuk menilai dan akhirnya menggunakan produk dan jasa keuangan tidak berdasarkan pengetahuan yang ada (Atkinson \& Messy, 2012).

Individu yang sadar secara finansial akan memiliki pengetahuan dasar tentang beberapa konsep utama keuangan (OECD, 2012). Huang et al. (2013) menganggap pengetahuan keuangan sebagai pemahaman konsep keuangan individu. Herd et al. (2012) menyatakan pengetahuan keuangan sebagai pengetahuan individu mengenai situasi keuangannya sendiri, daripada konsep keuangan dasar, dan memperlakukannya sebagai prasyarat untuk mengambil keputusan keuangan secara efektif. Pengetahuan keuangan adalah jenis modal khusus yang diperoleh dalam hidup melalui kemampuan untuk belajar mengelola pendapatan, pengeluaran, dan tabungan dengan cara yang aman (Delavande et al., 2008). Berdasarkan beberapa definisi tersebut, pengetahuan keuangan merupakan pengetahuan yang dimiliki oleh individu terkait dengan situasi keuangannya, sehingga mampu untuk mengambil keputusan berdasarkan kondisi keuangan yang ada.

Berdasarkan penelitian terdahulu terbukti bahwa pengetahuan keuangan berpengaruh terhadap perilaku keuangan individu. Tang \& Baker (2016) membuktikan bahwa pengetahuan keuangan berpengaruh terhadap perilaku keuangan. Hasil riset yang mendukung riset tersebut adalah Potrich et al. (2016) membuktikan bahwa pengetahuan keuangan berpengaruh terhadap perilaku keuangan. Sedangkan hasil penelitian Hadar et al. (2013) menyatakan bahwa pengaruh pengetahuan keuangan terhadap perilaku keuangan menunjukkan hasil yang tidak signifikan.

Selain pengetahuan keuangan, literasi keuangan memandang penting untuk memahami aspek terkait kepercayaan diri individu dalam memainkan peranan penting guna membentuk perilaku keuangan individu (Asaad, 2015). Kepercayaan diri secara luas dianggap sebagai aset penting yang dimiliki oleh seorang individu yang dapat membantu dalam mencapai kesuksesan pribadi (Gelaidan \& Abdullateef, 2017). Twibell et al. (2008) mendefinisikan kepercayaan diri sebagai perasaan manusiawi 
akan kepercayaan pada kualitas, kemampuan dan penilaiannya.

Xia et al. (2014) mengklaim bahwa individu dengan kepercayaan diri yang besar akan memiliki kecenderungan untuk tidak menggunakan pengetahuan yang mereka miliki, sehingga membentuk perilaku keuangan yang tidak baik. Individu dengan kepercayaan diri yang tinggi memiliki keyakinan bahwa mereka mampu membuat keputusan tanpa bantuan dan menjadi lebih rentan terhadap penipuan (Drew \& Cross, 2016; OECD, 2012).

Berdasarkan penelitian terdahulu terbukti bahwa kepercayaan diri berpengaruh terhadap perilaku keuangan individu. Ramalho \& Forte (2018) membuktikan bahwa kepercayaan diri berpengaruh terhadap perilaku keuangan. Hasil riset yang mendukung riset tersebut adalah Woodyard et al. (2017) membuktikan bahwa kepercayaan diri berpengaruh terhadap perilaku keuangan. Sedangkan hasil penelitian Arellano et al. (2014) menyatakan bahwa pengaruh kepercayaan diri terhadap perilaku keuangan menunjukkan hasil yang tidak signifikan pada beberapa tingkatan.

Orang yang tidak berpendidikan tidak mungkin menunjukkan literasi keuangan (Disney \& Gathergood, 2013) dan akibatnya, mereka mungkin kurang memiliki kepercayaan diri terkait aspek keuangan. Literasi keuangan memainkan peran utama dalam memungkinkan kepercayaan diri terkait aspek keuangan. Oleh karena itu, kepercayaan diri memiliki hubungan positif dengan prestasi dan kemampuan pendidikan keuangan yang baik. Lorz et al. (2013) menyatakan pengetahuan keuangan sebagai modal individu memiliki efek positif pada pembentukan kepercayaan diri individu terkait dengan aspek keuangan. Kepercayaan diri yang tumbuh mendorong individu untuk mengambil keputusan keuangan secara baik.

Berdasarkan penelitian terdahulu terbukti bahwa kepercayaan diri memediasi pengaruh pengetahuan keuangan terhadap perilaku keuangan individu. Ramalho \& Forte (2018) membuktikan bahwa kepercayaan diri memediasi pengaruh pengetahuan keuangan terhadap perilaku keuangan. Sedangkan hasil penelitian Flores (2014) menyatakan bahwa kepercayaan diri memediasi pengaruh pengetahuan keuangan terhadap perilaku keuangan.

Tujuan penelitian ini adalah menguji pengaruh pengetahuan keuangan terhadap perilaku keuangan, pengaruh pengetahuan keuangan terhadap kepercayaan diri, pengaruh kepercayaan diri terhadap perilaku keuangan. Tujuan lain dari penelitian ini adalah menguji peran mediasi kepercayaan diri pada pengaruh pengetahuan keuangan terhadap perilaku keuangan.

\section{KAJIAN PUSTAKA}

\subsection{Teori Sosial Kognitif}

Menurut Teori Sosial Kognitif, mahasiswa akan lebih cenderung mencoba, bertahan, dan mencoba untuk berhasil dalam kegiatan dan tugas ketika mereka memiliki rasa self-efficacy yang kuat (Bandura, 1986). Selfefficacy mengacu pada keyakinan bahwa seseorang bisa mencapai dan berhasil pada tugas yang diberikan disertai dengan motivasi, optimisme dan keyakinan bahwa seseorang dapat mengatasi berbagai tantangan kehidupan (Bandura, 1986). Kepercayaan diri individu merupakan bagi penting dalam self-efficacy yang mendorong individu untuk membuat suatu keputusan (Flores, 2014).

Terdapat hubungan yang kuat antara sejauh mana mahasiswa dengan self-efficacy yang baik dengan manajemen keuangan pribadi berdasarkan keterampilan literasi keuangan. Bandura (1986) menyatakan bahwa individu membuat keputusan hidup sehari-hari berdasarkan persepsi mereka terhadap mereka kemampuan di bidang tertentu. Demikian pula, mahasiswa membuat keputusan keuangan berdasarkan kemampuan yang dirasakan mereka. Bandura (1986) lebih lanjut menyatakan bahwa seseorang salah dalam menilai kemampuan yang dimiliki dapat menyebabkan hasil negatif, sehingga berdampak pada upaya untuk menghindari keputusan atau tugas tertentu. Mahasiswa dapat menghindar untuk menghadapi keputusan manajemen keuangan yang sulit, jika mereka belum berpengalaman positif karena kurangnya kepercayaan pada diri mereka. Karena itu, penting untuk pertimbangkan dampak kepercayaan diri pada literasi keuangan karena dapat mengindikasikan atau mengungkapkan kekurangan kepercayaan individu akan pengetahuan yang dimiliki sehingga sukar untuk menghasilkan keputusan keuangan yang baik.

\subsection{Literasi Keuangan}

Huston (2010) berpendapat bahwa literasi keuangan memiliki dua dimensi: pemahaman yang mewakili pengetahuan keuangan pribadi dari pendidikan keuangan, dan 
penggunaan yang mengacu pada manajemen pengetahuan keuangan pribadi. Dalam konteks ini, individu bisa memiliki pengetahuan keuangan, tetapi untuk dianggap memahami, ia harus memiliki kemampuan dan kepercayaan untuk mengimplementasikannya saat membuat keputusan. Hal ini menunjukkan bahwa literasi keuangan harus mencerminkan kemampuan individu untuk memahami informasi keuangan dan menggunakannya dengan terampil dan percaya diri (Huston, 2010). Pengetahuan keuangan individu memiliki peranan penting dalam literasi keuangan. Pengetahuan individu memiliki bagian penting dalam mengkoordinasikan keseluruhan aspek literasi keuangan dalam membentuk perilaku keuangan individu (Agarwalla et al., 2013; OECD, 2012).

\subsection{Perilaku Keuangan}

Perilaku keuangan merupakan elemen penting dari literasi keuangan, bahkan merupakan satu elemen paling penting (OECD, 2012). Dimensi perilaku keuangan merupakan penentu literasi keuangan (Lusardi \& Mitchell, 2014). Perilaku keuangan melihat pendekatan pengambilan keputusan individu, termasuk bias kognitif dan emosional. Perilaku keuangan membuat premis bahwa berbagai masalah obyektif dan subyektif mempengaruhi proses pengambilan keputusan.

Perilaku keuangan tumbuh dari sebuah sikap positif dari individu untuk mengelola keuangannya guna peningkatan kesejahteraan keuangan individu. Perilaku keuangan tidak dapat tumbuh dengan baik tanpa adanya sebuah pemahaman ide-ide mengenai konsep keuangan yang baik, sehingga mampu menghantarkan individu satu tindakan keuangan yang berguna bagi masa depannya.

Perilaku keuangan didefinisikan sebagai perilaku individu yang relevan dengan manajemen keuangan. Dalam definisi yang lain disebutkan bahwa perilaku keuangan dapat dijelaskan untuk mengevaluasi perilaku individu mengenai manajemen keuangan melalui tiga dimensi, yaitu: 1) Penggunaan kartu kredit yang mengarah kepada perilaku individu mengenai opsi kredit dan pembayaran kredit; 2) Konsumsi terencana yang mengarah kepada perilaku individu mengenai kontrol keuangan, penyusunan rencana biaya, dan pengendalian biaya; 3) Tabungan yang mengarah kepada perilaku individu mengenai perencanaan tabungan, pengalokasian cadangan keuangan, konsistensi (Potrich et al., 2016).

\subsection{Pengetahuan Keuangan}

Orang yang memahami keuangan akan memiliki pengetahuan dasar tentang beberapa konsep keuangan utama (OECD, 2012). Pengetahuan keuangan merupakan bentuk pemahaman individu mengenai konsep-konsep keuangan. Pemahaman konsep keuangan tersebut sesuai dengan pemahaman atas dasardasar manajemen keuangan. Hal ini menegaskan bahwa pengetahuan keuangan merupakan sebuah pengetahuan yang dimiliki oleh individu untuk mengelola finansialnya secara aman. Pengetahuan keuangan yang dimiliki individu menghantarkan individu untuk melakukan sebuah sikap yang bijak terkait dengan keputusan keuangan.

Pengetahuan keuangan didefinisikan sebagai pengetahuan individu mengenai situasi keuangannya sendiri yang dihasilkan dari pemahaman konsep keuangan dan memperlakukannya sebagai prasyarat untuk mengambil keputusan keuangan secara efektif. Dalam definisi yang lain disebutkan bahwa pengetahuan keuangan dapat dijelaskan melalui dua dimensi, yaitu: 1) Pengetahuan keuangan dasar yang mengarah kepada pengetahuan individu mengenai konsep dasar terkait dengan komposisi keuangan, meliputi: tarif pajak, inflasi, dan nilai uang berdasarkan waktu; 2) Pengetahuan keuangan lanjutan yang mengarah kepada pengetahuan individu mengenai instrumen-instrumen investasi, fungsi dari pasar modal, dan pemilihan investasi pada instrumen tertentu (Van Rooij et al., 2011).

\subsection{Kepercayaan Diri}

Individu dengan tingkat kompetensi atau kemampuan yang tinggi akan meningkatkan penilaian positif terhadap dirinya. Individu tersebut menyadari kemampuan yang dimiliki serta berupaya untuk memanfaatkannya secara tepat. Sikap positif individu dalam memandang potensi kemampuannya sendiri untuk bertingkah laku sesuai dengan yang diharapkannya sebagai suatu perasaan yang yakin pada tindakannya, bertanggung jawab terhadap tindakannya dan tidak terpengaruh oleh orang lain.

Kepercayaan diri terkait aspek keuangan didefinisikan sebagai sikap positif individu atas pengetahuan dan kompetensi terkait dengan aspek keuangan. Dalam definisi yang lain disebutkan bahwa kepercayaan diri terkait aspek keuangan dapat dijelaskan melalui penilaian diri 


\section{Owner \\ RISET \& JURNAL AKUNTANSI \\ RISET \& JURNAL AKUNTANSI \\ Volume 3 Nomor 2, Agustus 2019 \\ e-ISSN : 2548-9224 \\ https://doi.org/10.33395/owner.v3i2.147 p-ISSN : 2548-7507}

individu mengenai pengetahuan keuangan yang dimiliki (Ramalho \& Forte, 2018).

\subsection{Hubungan Pengetahuan Keuangan dan Perilaku Keuangan}

Pemahaman manajemen keuangan yang baik membentuk sebuah pengetahuan keuangan yang baik dalam diri individu. Mahasiswa akuntansi merupakan individu dengan tingkat pengetahuan keuangan yang baik, dikarenakan mahasiswa akuntansi merupakan individu yang mengalami proses pembelajaran terkait dengan aspek keuangan yang kompleks. Pengetahuan keuangan mahasiswa akuntansi diharapkan mampu membentuk keputusan keuangan yang selektif. Pengetahuan keuangan yang baik pada mahasiswa akuntansi melahirkan sebuah keterampilan keuangan yang diharapkan, sehingga mampu mengubah perilaku dan kemampuan mereka untuk memecahkan masalah keuangan sehari-hari. Keterampilan kognitif yang terbentuk pada mahasiswa akuntansi terkait dengan aspek keuangan merupakan bentuk pembelajaran yang memengaruhi kemampuan seseorang untuk mewujudkan hasil dan akibatnya terhadap perilaku.

Hasil penelitian yang dilakukan oleh Potrich et al. (2016) membuktikan bahwa pengetahuan keuangan berpengaruh positif dan signifikan terhadap perilaku keuangan mahasiswa. Hal ini berarti semakin baik pengetahuan keuangan yang dimiliki oleh mahasiswa akan membentuk perilaku keuangan yang baik. Sejalan dengan penelitian Potrich et al. (2016), penelitian yang dilakukan Tang \& Baker, (2016) membuktikan bahwa pengetahuan keuangan berpengaruh positif dan signifikan terhadap perilaku keuangan. Berdasarkan temuan dua peneliti terdahulu yang menyatakan bahwa terdapat pengaruh pengetahuan keuangan terhadap perilaku keuangan, maka dalam penelitian ini dapat dirumuskan hipotesis sebagai berikut.

H1: Pengetahuan keuangan berpengaruh positif terhadap perilaku keuangan

\subsection{Hubungan Pengetahuan Keuangan dan Kepercayaan Diri}

Pembelajaran aspek keuangan yang kompleks pada mahasiswa akuntansi akan meningkatkan pengetahuan keuangan dalam diri mahasiswa. Meningkatnya pengetahuan keuangan yang dimiliki oleh mahasiswa akuntansi akan mendorong mahasiswa untuk memiliki kepercayaan diri yang lebih baik dalam pengelolaan keuangan mereka. Mahasiswa akuntansi memiliki kesadaran bahwa pengetahuan yang dimiliki memberikan manfaat bagi diri mereka dalam mengelola aspek keuangan pribadi. Kemampuan pada bidang akuntansi dan keuangan memberikan kemudahan bagi mahasiswa akuntansi dalam membuat keputusan keuangan, sehingga kemampuan kognitif terkait dengan keuangan tersebut akan meningkatkan kepercayaan diri mahasiswa terkait aspek keuangan.

Hasil penelitian yang dilakukan oleh Ramalho \& Forte (2018) membuktikan bahwa pengetahuan keuangan berpengaruh positif dan signifikan terhadap kepercayaan diri. Hal ini berarti semakin baik pengetahuan keuangan yang dimiliki oleh individu membentuk kepercayaan diri yang tinggi. Sejalan dengan penelitian Ramalho \& Forte (2018), penelitian yang dilakukan Asaad (2015) membuktikan bahwa pengetahuan keuangan berpengaruh positif dan signifikan terhadap kepercayaan diri. Berdasarkan temuan dua peneliti terdahulu yang menyatakan bahwa terdapat pengaruh pengetahuan keuangan terhadap kepercayaan diri, maka dalam penelitian ini dapat dirumuskan hipotesis sebagai berikut.

H2: Pengetahuan keuangan berpengaruh positif terhadap kepercayaan diri

\subsection{Hubungan Kepercayaan Diri dan Perilaku Keuangan}

Kepercayaan diri yang tinggi pada diri mahasiswa akuntansi terkait dengan aspek keuangan memberikan dorongan kepada mahasiswa untuk melakukan sebuah tindakan keuangan yang lebih besar dibandingkan dengan individu lainnya. Kepercayaan diri yang muncul akibat pengetahuan yang dimiliki mendorong mahasiswa untuk membuat perencanaanperencanaan keuangan yang lebih baik dan mengambil sebuah kesempatan yang lebih untuk meningkatkan keuangan mereka. Kepercayaan diri yang tinggi pada diri mahasiswa akuntansi terkait aspek keuangan mendorong mahasiswa akuntansi untuk berperilaku lebih baik dengan mengikuti prinsip-prinsip manajemen keuangan yang berlaku.

Hasil penelitian yang dilakukan oleh Ramalho \& Forte (2018) membuktikan bahwa kepercayaan diri berpengaruh positif dan signifikan terhadap perilaku keuangan. Hal ini berarti semakin tinggi kepercayaan diri yang dimiliki oleh individu membentuk membentuk 
perilaku keuangan yang baik. Sejalan dengan penelitian Ramalho \& Forte (2018), penelitian yang dilakukan Allgood \& Walstad (2016) membuktikan bahwa kepercayaan diri berpengaruh positif dan signifikan terhadap perilaku keuangan. Berdasarkan temuan dua peneliti terdahulu yang menyatakan bahwa terdapat pengaruh kepercayaan diri terhadap perilaku keuangan, maka dalam penelitian ini dapat dirumuskan hipotesis sebagai berikut.

H3: Kepercayaan diri berpengaruh positif terhadap perilaku keuangan

\subsection{Hubungan Pengetahuan Keuangan, Kepercayaan Diri, dan Perilaku Keuangan}

Individu dengan tingkat pengetahuan keuangan rendah tidak mungkin menunjukkan literasi keuangan. Hal ini mengakibatkan individu dengan pengetahuan keuangan yang rendah kurang memiliki kepercayaan diri terkait aspek keuangan. Literasi keuangan memainkan peran utama dalam memungkinkan kepercayaan diri terkait aspek keuangan. Pengetahuan keuangan memiliki peran penting dalam membentuk kepercayaan diri individu terkait dengan aspek keuangan. Kepercayaan diri yang muncul dalam diri individu mendorong individu untuk membuat perencanaan keuangan yang lebih baik, sehingga mereka akan lebih termotivasi untuk berperilaku keuangan yang baik.

Hasil penelitian yang dilakukan oleh Ramalho \& Forte (2018) membuktikan bahwa kepercayaan diri memediasi pengaruh pengetahuan keuangan terhadap perilaku keuangan. Hal ini berarti semakin tinggi pengetahuan keuangan individu akan membentuk kepercayaan diri yang tinggi, sehingga kepercayaan diri tersebut akan membentuk perilaku keuangan yang baik. Sejalan dengan penelitian Ramalho \& Forte (2018), penelitian yang dilakukan Allgood \& Walstad (2016) membuktikan bahwa kepercayaan diri berpengaruh positif dan signifikan terhadap perilaku keuangan. Berdasarkan temuan dua peneliti terdahulu yang menyatakan bahwa terdapat pengaruh kepercayaan diri terhadap perilaku keuangan, maka dalam penelitian ini dapat dirumuskan hipotesis sebagai berikut.

H4: Kepercayaan diri memediasi pengaruh positif pengetahuan keuangan terhadap perilaku keuangan

\section{METODE PENELITIAN}

Penelitian dilakukan di jurusan Akuntansi Universitas Airlangga. Alasan dipilihnya jurusan Akuntansi Universitas Airlangga dikarenakan Universitas Airlangga merupakan salah satu kampus negeri terbaik di Indonesia yang menyelenggarakan pendidikan ekonomi dan keuangan. Adapun populasi penelitian ini adalah mahasiswa jurusan Akuntansi Universitas Airlangga. mahasiswa jurusan Akuntansi Universitas Airlangga hingga tahun 2018 berjumlah 1981 mahasiswa. Teknik purposive sampling digunakan dalam penelitian ini, dengan pertimbangan responden yang dijadikan sampel adalah mahasiswa yang telah menempuh mata kuliah Akuntansi Keuangan Lanjutan dengan asumsi mahasiswa yang telah menempuh mata kuliah Akuntansi Keuangan Lanjutan memiliki pengetahuan yang lebih baik terhadap aspek keuangan. Berdasarkan hasil perhitungan, jumlah sampel minimal dalam penelitian ini sebesar 215 responden. Selanjutnya kuesioner disebarkan kepada 463 responden, akan tetapi dengan pertimbangan kelayakan dan konsistensi jawaban, maka penelitian ini menggunakan 328 kuesioner sebagai sampel.

\subsection{Definisi Operasional Variabel dan Indikator \\ Variabel yang digunakan dalam} penelitian ini meliputi perilaku keuangan, pengetahuan keuangan, dan kepercayaan diri. Perilaku keuangan didefinisikan sebagai perilaku individu yang relevan dengan manajemen keuangan, diukur dengan indikator: 1) Penggunaan kartu kredit; 2) Konsumsi terencana; 3) Tabungan (Potrich et al., 2016).

Variabel kedua adalah pengetahuan keuangan yang didefinisikan sebagai pengetahuan individu mengenai situasi keuangannya sendiri yang dihasilkan dari pemahaman konsep keuangan dan memperlakukannya sebagai prasyarat untuk mengambil keputusan keuangan secara efektif, diukur dengan indikator: 1) Pengetahuan keuangan dasar; 2) Pengetahuan keuangan lanjutan (Van Rooij et al., 2011).

Selanjutnya variabel ketiga adalah kepercayaan diri yang didefinisikan sebagai sikap positif individu atas pengetahuan dan kompetensi terkait dengan aspek keuangan, diukur dengan indikator: 1) Penilaian diri atas kemampuan pengetahuan keuangan (Ramalho \& Forte, 2018). 


\subsection{Teknik Analisis}

Penelitian ini menggunakan metode analisis konfirmatori untuk menguji hipotesis dengan menggunakan analisis Structural Equation Model (SEM). Analisis Structural Equation Model (SEM) menggunakan pendekatan Partial Least Square (PLS) dengan bantuan software WarpPLS 5.0. Estimasi yang di dapat dengan menggunakan WarpPLS 5.0 meliputi dua kategori yaitu: 1) Estimasi jalur (path estimate) yang menghubungkan variabel laten dan antar variabel laten serta blok indikatornya (loading); 2) Estimasi lokasi parameter untuk indikator dan variable laten.

Untuk memperoleh kedua estimasi tersebut, PLS menggunakan proses iterasi dua tahap dan setiap tahap estimasi menghasilkan estimasi. Tahap pertama menghasilkan estimasi lokasi parameter. Selanjutnya tahap kedua dilakukan proses iterasi untuk menghasilkan estimasi jalur yang menghubungkan variabel laten dengan variabel laten lainnya.

\section{HASIL DAN PEMBAHASAN}

\subsection{Karakteristik Responden}

Responden penelitian adalah mahasiswa Akuntanasi Universitas Airlangga dengan jumlah 328 mahasiswa. Tabel 1 dan Tabel 2 menjelaskan sebaran berdasarkan usia dan jenis kelamin responden.

Tabel 1

Sebaran Umur Responden

\begin{tabular}{|c|c|c|c|}
\hline $\mathbf{N}$ & & Jumla & \\
\hline $\mathbf{o}$ & Umur (Th) & $\mathbf{h}$ & $\%$ \\
\hline & 20 & 50 & 15 , \\
\hline 1 & & & 1 \\
\hline & 21 & 193 & 58 \\
\hline 2 & & & 9 \\
\hline & 22 & 68 & 20 , \\
\hline 3 & & & 6 \\
\hline 4 & 23 & 11 & 3,5 \\
\hline 5 & Lainnya & 6 & 1,9 \\
\hline
\end{tabular}

Sumber: Data primer diolah, 2018.

Berdasarkan usia, sebagian besar mahasiswa berusia 21 tahun yaitu sebanyak 193 orang atau 58,9 persen dari total responden. Hal tersebut dapat menggambarkan mahasiswa yang telah menempuh mata kuliah Akuntansi Keuangan Lanjutan didominasi oleh mahasiswa dengan usia 21 tahun. Hal ini mengindikasikan pada usia tersebut pengetahuan keuangan mahasiswa sudah cukup baik sebagai dasar dalam literasi keuangan.

Tabel 2

\begin{tabular}{clrl}
\multicolumn{4}{c}{ Sebaran Jenis Kelamin Responden } \\
\hline No & Jenis Kelamin & Jumlah & \multicolumn{1}{c}{$\%$} \\
\hline 1 & Laki- Laki & 94 & 28,7 \\
2 & Perempuan & 234 & 71,3 \\
\hline
\end{tabular}

Sumber: Data primer diolah, 2018.

Sebaran responden berdasarkan jenis kelamin, sebagian besar responden berjenis kelamin perempuan yaitu sebanyak 234 orang atau 71,3 persen dari total responden. Kondisi ini menunjukkan bahwa mahasiswa akuntansi Universitas Airlangga didominasi oleh perempuan. Selain itu, data menunjukkan bahwa perempuan memiliki ketertarikan yang lebih besar dalam bidang akuntansi dan keuangan.

Tabel 3

Sumber Keuangan

\begin{tabular}{|c|c|c|c|}
\hline No & Sumber Keuangan & Jumlah & $\%$ \\
\hline 1 & Orang tua & 275 & 83,7 \\
\hline 2 & Diri Sendiri & 53 & 53 \\
\hline
\end{tabular}

diolah, 2018.

Berdasarkan sumber keuangan yang diterima responden, sebanyak $83,7 \%$ responden memperoleh uang dari orang tua mereka. Hal itu menunjukkan bahwa sebagian besar responden belum bekerja sehingga sumber pendapatan mereka berasal dari orang tua.

Tabel 5

Besar Pendapatan Bulanan

\begin{tabular}{|c|c|c|c|}
\hline No & Pendapatan (Rp) & Jumlah & $\%$ \\
\hline 1 & $\leq 1.000 .000$ & 23 & 7,1 \\
\hline 2 & $\begin{array}{l}1.000 .001 \text { sampai } \leq \\
2.000 .000\end{array}$ & 199 & 60,7 \\
\hline 3 & $>2.000 .000$ & 106 & 32.2 \\
\hline
\end{tabular}
diterima, sebanyak $60,7 \%$ responden memiliki pendapatan antara satu juta sampai kurang dari dua juta rupiah. Hal itu menunjukkan bahwa uang saku yang responden terima berkisar antara satu juta hingga dua juta rupiah per bulan.

\subsection{Hasil Model Pengukuran}

Uji validitas digunakan untuk mengukur valid atau tidaknya suatu kuesioner. Suatu kuesioner dikatakan valid jika pernyataan pada kuesioner/ indikator mampu untuk mengungkapkan sesuatu yang akan diukur oleh kuesioner tersebut. Uji validitas dengan program WarpPLS 5.0 dilakukan dengan menggunakan 
ukuran: 1) Convergent validity; dan 2) Composite reliability.

\subsubsection{Convergent Validity}

Convergent validity dari model pengukuran refleksif indicator dinilai berdasarkan korelasi antara item scorel component score yang diestimasi dengan nilai outer loading factor. Batas minimum nilai outer loading factor suatu indikator yang layak digunakan untuk merefleksikan suatu variabel adalah sebesar 0,5 (Chin, 1998).

Tabel 6

Hasil Outer Loading Factor

\begin{tabular}{cccc}
\hline & $\begin{array}{c}\text { Perilaku } \\
\text { Keuanga } \\
\text { n }\end{array}$ & $\begin{array}{c}\text { Keperca } \\
\text {-yaan } \\
\text { Diri }\end{array}$ & $\begin{array}{c}\text { Pengetahuan } \\
\text { Keuangan }\end{array}$ \\
\hline FB1 & 0,739 & & \\
FB4 & 0,807 & & \\
FB5 & 0,696 & & \\
FB6 & 0,636 & & \\
FB9 & 0,68 & & \\
FB1 & & & \\
1 & 0,685 & & \\
SC & & 1 & 0,768 \\
FKB & & & 0,768 \\
FKA & & & \\
\hline
\end{tabular}

Sumber: Data primer diolah, 2018.

Hasil perhitungan menunjukkan bahwa setiap konstruk yang dijadikan model penelitian memiliki nilai outer loading factor lebih besar dari 0,5 sehingga konstruk tersebut dikatakan valid untuk model penelitian.

Tabel 7

Hasil Average Variance Extacted (AVE) Average Variance Extracted (AVE)

\begin{tabular}{lc} 
& (AVE) \\
\hline $\begin{array}{l}\text { Pengetahuan } \\
\text { Keuangan }\end{array}$ & 0.590 \\
$\begin{array}{l}\text { Kepercayaan } \\
\text { Diri }\end{array}$ & 1.000 \\
$\begin{array}{l}\text { Perilaku } \\
\text { Keuangan }\end{array}$ & 0.503 \\
\hline Sumber: Data primer diolah, 2018.
\end{tabular}

Sumber: Data primer diolah, 2018.

Berdasarkan hasil AVE pada tabel 7, semua konstruk bernilai lebih besar dari 0,5, sehingga uji convergent validity dapat diterima. Hal ini menunjukkan bahwa pengukur-pungukur (manifest variable) setiap konstruk berkorelasi tinggi terhadap konstruknya.

\subsubsection{Composite Reliability}

Composite reliability digunakan untuk menguji reliabilitas suatu konstruk. Uji reliabilitas terpenuhi apabila nilai composite reliability lebih besar dari 0,7

Tabel 8

Hasil Composite Reliability

\begin{tabular}{lc}
\hline & Composite Reliability \\
\hline $\begin{array}{l}\text { Pengetahuan } \\
\text { Keuangan }\end{array}$ & 0.742 \\
Kepercayaan & \\
Diri & 1.000 \\
$\begin{array}{l}\text { Perilaku } \\
\text { Keuangan }\end{array}$ & 0.858 \\
\hline Sumber: &
\end{tabular}

Sumber: Data primer diolah, 2018.

Berdasarkan hasil perhitungan composite reliability menunjukkan seluruh konstruk memiliki nilai lebih besar dari 0,7. Hal ini berarti bahwa seluruh konstruk dalam penelitian adalah reliabel.

Berdasarkan uji validitas dan reliabilitas, maka dapat disimpulkan bahwa seluruh konstruk penelitian (perilaku keuangan, pengetahuan keuangan, dan kepercayaan diri) valid dan reliabel, sehingga seluruh konstruk penelitian dapat dilakukan analisis lebih lanjut untuk menjawab permasalahan penelitian.

\subsection{Hasil Model Struktural (Inner Model)}

Hasil pengolahan data dengan menggunakan software WarpPLS 5.0 bertujuan untuk mengetahui ada tidaknya pengaruh pengetahuan keuangan terhadap perilaku keuangan dengan di mediasi oleh kepercayaan diri. Grafik berikut merupakan hasil perhitungan dari model struktural yang dibangun dalam penelitian.

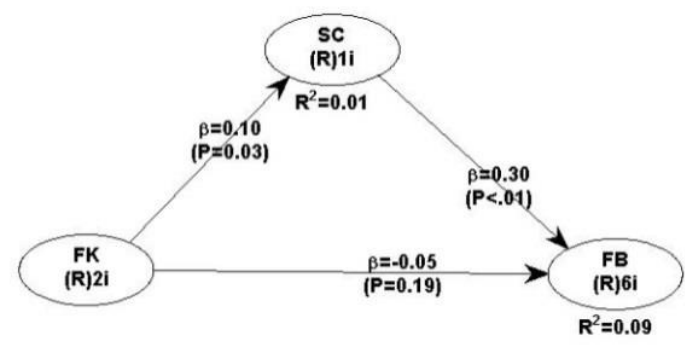

Gambar 1

Hasil Model Struktural

Inner model dihitung dengan menggunakan nilai $R$-square untuk konsruk dependen, Stone-Geisser $Q$-square test untuk perdiktif relevan, uji-t serta signifikasi dari koefisien parameter jalur struktural dan uji Sobel 
serta signifikasi dari koefisisen.

Nilai $Q$-square predictive relevance digunakan untuk mengukur seberapa baik nilai observasi dihasilkan oleh model dan juga estimasi parameternya. Nilai $Q$-square predictive relevance lebih besar dari 0 (nol) menunjukkan bahwa model mempunyai prediktif relevan, sedangkan apabila nilai $Q$-square kurang dari 0 (nol) menunjukkan bahwa model kurang mempunyai prediktif relevan.

Nilai $Q$-square predictive relevance dihitung dengan menggunakan rumus:

$$
\begin{aligned}
\mathrm{Q}^{2} & =1-\left(1-\mathrm{R}^{2} \mathrm{SC}\right) \times\left(1-\mathrm{R}^{2} \mathrm{FB}\right) \\
& =1-(1-0,010) \times(1-0,086) \\
& =1-(0,99) \times(0,914) \\
& =1-0,90486 \\
& =0,09514
\end{aligned}
$$

Nilai $Q$-square predictive relevance adalah 0,09514 atau 9,514 persen. Hasil ini menunjukkan bahwa model penelitian memiliki nilai prediktif relevan, sehingga dapat digunakan. Selain itu, nilai ini menunjukkan bahwa model memiliki prediktif relevan yang lemah.

\subsection{Pengujian Hipotesis}

Pengujian hipotesis merupakan tahapan dalam menguji permasalahan yang dibangun dalam penelitian dengan membandingkan kenyataan dengan dugaan sementara penelitian. Pengujian hipotesis didasarkan pada hasil pengolahan data dengan menggunakan software WarpPLS 5.0 dengan melihat hasil perhitungan koefisien jalur serta signifikasi koefisien parameter jalur struktural. Selain itu, digunakan uji Sobel untuk membuktikan adanya pengaruh mediasi pada jalur struktural yang ada dengan menihat nilai signifikasi koefisien parametenya. Hipotesis penelitian diterima apabila signifikasi koefisien jalur struktural lebih kecil dari 0,05.

\section{Tabel 9}

Hasil Perhitungan Koefisien Jalur

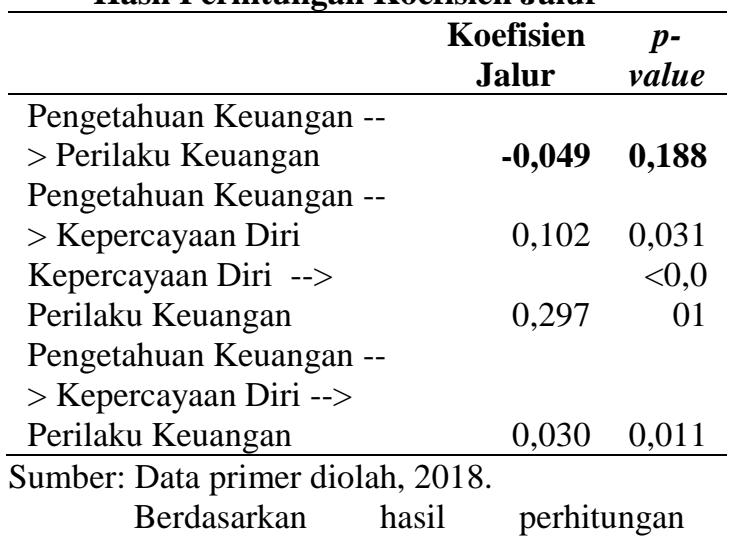

signifikasi koefisien jalur struktural menunjukkan jalur struktural pengaruh pengetahuan keuangan terhadap kepercayaan diri, pengaruh kepercayaan diri terhadap perilaku keuangan. Hal ini ditujukkan dari nilai signifikasi koefisien parameter jalur struktural ( $p$-value) lebih kecil dari 0,05. Sementara itu, jalur struktural pengaruh pengetahuan keuangan tidak berpengaruh terhadap perilaku keuangan. Hal ini ditujukkan dari nilai signifikasi koefisien parameter jalur struktural ( $p$-value) lebih besar dari 0,05 .

Berdasarkan hasil perhitungan signifikasi koefisien jalur struktural pengaruh tidak langsung menunjukkan seluruh jalur struktural yang dibangun dalam penelitian memiliki pengaruh tidak langsung. Hal ini ditujukkan dari nilai signifikasi koefisien parameter jalur struktural ( $p$-value) mediasi kepercayaan diri pada pengaruh pengetahuan keuangan terhadap perilaku keuangan lebih kecil dari 0,05 .

\subsection{Pengaruh Pengetahuan Keuangan Terhadap Perilaku Keuangan \\ Berdasarkan hasil pengujian hipotesis} menunjukkan bahwa probabilitas kesalahan ( $p$ value) pengaruh pengetahuan keuangan terhadap perilaku keuangan sebesar 0,188. Hasil pengujian memberikan temuan bahwa $p$-value > 0,05 . Hasil ini tidak mendukung hipotesis yang menyatakan pengetahuan keuangan berpengaruh terhadap perilaku keuangan. Nilai path coefficient pengaruh pengetahuan keuangan terhadap perilaku keuangan sebesar -0,049 artinya pengetahuan keuangan berpengaruh negatif terhadap perilaku keuangan.

Hasil pengujian hipotesis menunjukkan bahwa pengetahuan keuangan yang dimiliki oleh mahasiswa tidak memberikan dampak yang cukup berarti dalam mengubah keputusan keuangan mahasiswa. Pengetahuan keuangan yang dimiliki oleh mahasiswa tidak memberikan pilihan terkait dengan keputusan keuangan mahasiswa yang bersifat terbatas. Mahasiswa sebagai invidu yang sebagian besar belum memiliki penghasilan tidak memiliki banyak pilihan terkait dengan keputusan keuangan, sehingga perubahan perilaku keuangan mahasiswa menjadi terbatas.

Hasil penelitian ini sejalan dengan penelitian yang dilakukan oleh Hadar et al. (2013) yang menemukan bukti empiris bahwa pengetahuan keuangan tidak berpengaruh terhadap perilaku keuangan. Hadar et al. (2013) 
menyimpulkan bahwa pengetahuan keuangan tidak harus berfokus pengetahuan keuangan obyektif, tetapi juga mempertimbangkan tingkat pengetahuan keuangan subyektif. Baik pengetahuan keuangan obyektif dan subyektif harus dipertimbangkan dalam upaya untuk mendidik individu untuk membantu mereka mengelola keuangan dengan bijaksana.

\subsection{Pengaruh Pengetahuan Keuangan Terhadap Kepercayaan Diri \\ Berdasarkan hasil pengujian hipotesis} menunjukkan bahwa probabilitas kesalahan ( $p$ value) pengaruh pengetahuan keuangan terhadap kepercayaan diri sebesar 0,031 . Hasil pengujian memberikan temuan bahwa $p$-value $<0,05$. Hasil ini mendukung hipotesis yang menyatakan pengetahuan keuangan berpengaruh terhadap kepercayaan diri. Nilai path coefficient pengaruh pengetahuan keuangan terhadap kepercayaan diri sebesar 0,102 artinya pengetahuan keuangan berpengaruh positif kepercayaan diri.

Hasil pengujian hipotesis menunjukkan bahwa pengetahuan keuangan yang dimiliki oleh mahasiswa memberikan dampak yang besar dalam membentuk kepercayaan diri mahasiswa terkait dengan aspek keuangan. Mahasiswa akuntansi memiliki kesadaran bahwa pengetahuan yang dimiliki memberikan manfaat bagi diri mereka dalam mengelola aspek keuangan pribadi. Kemampuan pada bidang akuntansi dan keuangan memberikan kemudahan bagi mahasiswa akuntansi dalam membuat keputusan keuangan, sehingga kemampuan kognitif terkait dengan keuangan tersebut akan meningkatkan kepercayaan diri mahasiswa terkait aspek keuangan.

Hasil penelitian ini sejalan dengan penelitian yang dilakukan oleh Ramalho \& Forte (2018) dan Asaad (2015) yang menemukan bukti empiris bahwa pengetahuan keuangan berpengaruh terhadap kepercayaan diri. Ramalho \& Forte (2018) dan Asaad (2015) menyimpulkan bahwa pengetahuan keuangan berpengaruh positif dan signifikan terhadap kepercayaan diri.

\subsection{Pengaruh Kepercayaan Diri Terhadap Perilaku Keuangan}

Berdasarkan hasil pengujian hipotesis menunjukkan bahwa probabilitas kesalahan ( $p$ value) pengaruh pengetahuan keuangan terhadap kepercayaan diri sebesar 0,001 . Hasil pengujian memberikan temuan bahwa $p$-value $<0,05$. Hasil ini mendukung hipotesis yang menyatakan kepercayaan diri berpengaruh terhadap perilaku keuangan. Nilai path coefficient pengaruh kepercayaan diri terhadap perilaku keuangan sebesar 0,297 artinya kepercayaan diri berpengaruh positif terhadap perilaku keuangan.

Hasil pengujian hipotesis menunjukkan bahwa kepercayaan diri yang dimiliki oleh mahasiswa terkait aspek kepuangan memberikan dampak yang besar dalam membentuk perilaku keuangan. Mahasiswa akuntansi merupakan individu dengan pengetahuan keuangan yang baik akan membuat sebuah tindakan-tindakan keuangan yang lebih komplek dibandingkan dengan individu lain. Hal ini dikarenakan pengetahuan keuangan yang lebih baik dari mahasiswa akuntansi akan mendorong mahasiswa untuk membuat sebuah tindakan keuangan baru sebagai pembelajaran dari pengetahuan yang dimiliki. Kepercayaan diri yang tinggi pada diri mahasiswa akuntansi dengan menjalankan tindakan-tindakan keuangan baru menimbulkan sebuah resiko, sehingga untuk mengurangi resiko yang timbul, mahasiswa harus mampu membuat keputusan keuangan yang baik sesuai dengan prinsip keuangan yang berlaku.

Hasil penelitian ini sejalan dengan penelitian yang dilakukan oleh Ramalho \& Forte (2018) dan Allgood \& Walstad (2016) yang menemukan bukti empiris bahwa kepercayaan diri berpengaruh terhadap perilaku keuangan. Ramalho \& Forte (2018) dan Allgood \& Walstad (2016) menyimpulkan bahwa semakin tinggi kepercayaan diri yang dimiliki oleh individu membentuk membentuk perilaku keuangan yang baik.

\subsection{Kepercayaan Diri Memediasi Pengaruh Pengetahuan Keuangan Terhadap Perilaku Keuangan}

Berdasarkan hasil pengujian hipotesis menunjukkan bahwa probabilitas kesalahan ( $p$ value) pada uji Sobel sebesar 0,011. Hasil pengujian memberikan temuan bahwa $p$-value < 0,05 . Hasil ini mendukung hipotesis yang menyatakan kepercayaan diri mampu memediasi pengaruh pengetahuan keuangan terhadap perilaku keuangan. Hasil temuan mengindikasikan meningkatnya pengetahuan keuangan yang dimiliki mahasiswa akuntansi akan meningkatkan kepercayaan diri mahasiswa terkait dengan aspek keuangan, sehingga kepercayaan diri yang tumbuh mampu membentuk perilaku keuangan yang baik terutama terkait dengan pengambilan keputusan 
keuangan.

Hasil penelitian mengindikasikan bahwa pengetahuan keuangan dasar dan pengetahuan keuangan lanjutan yang dimiliki mahasiswa akan menjadi sumber pengetahuan keuangan bagi mahasiswa. Pengetahuan keuangan menjadi sumber bagi mahasiswa untuk meningkatkan kompetensi atau kemampuan mereka menjadi lebih tinggi, sehingga hal ini mendorong mahasiswa untuk meningkatkan penilaian positif terhadap dirinya. Sikap positif mahasiswa akuntansi dalam memandang kemampuan pengetahuan keuangannya mencoba untuk bertingkah laku sesuai dengan yang diharapkannya sebagai suatu perasaan yang yakin pada tindakannya, bertanggung jawab terhadap tindakannya dan tidak terpengaruh oleh orang lain. Hal ini membentuk kepercayaan diri yang tinggi pada mahasiswa akuntansi untuk mengaplikasikan pengetahuan keuangan yang dimiliki dalam membentuk sebuah tindakan keuangan tertentu. Dalam menjalankan tindakan keuangan tersebut, maka mahasiswa akuntansi harus mampu mempetimbangkan secara baik, sehingga perilaku dalam proses mengambil keputusan menjadi faktor penting bagi mahasiswa akuntansi dalam menghasilkan keputusan yang baik.

Hasil penelitian ini sejalan dengan penelitian yang dilakukan oleh Ramalho \& Forte (2018) dan Allgood \& Walstad (2016) yang menyatakan bahwa kepercayaan diri memediasi pengaruh pengetahuan keuangan terhadap perilaku keuangan. Hal ini berarti semakin tinggi pengetahuan keuangan individu akan membentuk kepercayaan diri yang tinggi, sehingga kepercayaan diri tersebut akan membentuk perilaku keuangan yang baik.

\section{SIMPULAN}

Berdasarkan pengujian hipotesis penelitian dapat disimpulkan bahwa pengetahuan keuangan berpengaruh positif terhadap kepercayaan diri, kepercayaan diri berpengaruh positif terhadap perilaku keuangan, dan kepercayaan diri memediasi pengaruh pengetahuan keuangan terhadap perilaku keuangan Hasil ini mengindikasikan pengetahuan keuangan memiliki peranan penting dalam meningkatkan kepercayaan diri mahasiswa akuntansi, sehingga kepercayaan diri yang tumbuh dalam diri mendorong mahasiswa untuk membuat keputusan keuangan yang baik, sehingga perilaku terkait dengan aspek keuangan akan semakin meningkat.

\section{DAFTAR PUSTAKA}

Agarwalla, S. K., Barua, S. K., Jacob, J., \& Varma, J. R. (2013). Financial literacy among working young in urban India. Indian Institute of Management Ahmedabad, WP, (2013-10), 2.

Allgood, S., \& Walstad, W. B. (2016). The effects of perceived and actual financial literacy on financial behaviors. Economic Inquiry, 54(1), 675-697.

Arellano, A., Cámara, N., \& Tuesta, D. (2014). The effect of self-confidence on financial literacy. BBVA Research WP, 14, 28.

Asaad, C. T. (2015). Financial literacy and financial behavior: Assessing knowledge and confidence. Financial Services Review, 24(2), 101-118.

Atkinson, A., \& Messy, F.-A. (2012). Measuring financial literacy.

Baker, H. K., \& Ricciardi, V. (2014). Investor behavior: The psychology of financial planning and investing. John Wiley \& Sons.

Bandura, A. (1986). Social foundations of thought and action. Englewood Cliffs, NJ, 1986.

Chin, W. W. (1998). The partial least squares approach to structural equation modeling. Modern Methods for Business Research, 295(2), 295-336.

Delavande, A., Rohwedder, S., \& Willis, R. J. (2008). Retirement planning and the role of financial literacy and cognition. Michigan Retirement Research Center Working Paper, 190.

Disney, R., \& Gathergood, J. (2013). Financial literacy and consumer credit portfolios. Journal of Banking \& Finance, 37(7), 2246-2254.

Drew, J. M., \& Cross, C. (2016). Fraud and its PREY: Conceptualising social engineering tactics and its impact on financial literacy outcomes. In Financial Literacy and the Limits of Financial Decision-Making (pp. 325-340). Springer.

Flores, C. (2014). First generation college student financial literacy: Impact of self-efficacy and behavior.

Gelaidan, H. M., \& Abdullateef, A. O. (2017). Entrepreneurial intentions of business students in Malaysia: the role of self-confidence, educational and relation support. Journal of Small Business and Enterprise Development, 24(1), 54-67.

Grable, J. E., \& Joo, S.-H. (2004). Environmental and biophysical factors associated with financial risk tolerance. 
Hadar, L., Sood, S., \& Fox, C. R. (2013). Subjective knowledge in consumer financial decisions. Journal of Marketing Research, 50(3), 303-316.

Herd, P., Holden, K., \& Su, Y. T. (2012). The links between early-life cognition and schooling and late-life financial knowledge. Journal of Consumer Affairs, 46(3), 411-435.

Huang, J., Nam, Y., \& Sherraden, M. S. (2013). Financial knowledge and child development account policy: A test of financial capability. Journal of Consumer Affairs, 47(1), 1-26.

Huston, S. J. (2010). Measuring financial literacy. Journal of Consumer Affairs, 44(2), 296-316.

Lorz, M., Mueller, S., \& Volery, T. (2013). Entrepreneurship education: a systematic review of the methods in impact studies. Journal of Enterprising Culture, 21(2), 123-151.

Lusardi, A., \& Mitchell, O. S. (2014). The economic importance of financial literacy: Theory and evidence. Journal of Economic Literature, $52(1), 5-44$.

Lyons, A. C. (2004). A profile of financially at-risk college students. Journal of Consumer Affairs, $38(1), 56-80$.

OECD. (2012). OECD/INFE high-level principles on national strategies for financial education. OECD Publishing.

Potrich, A. C. G., Vieira, K. M., \& Mendes-Da-Silva, W. (2016). Development of a financial literacy model for university students. Management Research Review, 39(3), 356-376.

Ramalho, T. B., \& Forte, D. (2018). Financial literacy in Brazil - Do knowledge and self-confidence relate with behavior? RAUSP Management Journal. https://doi.org/10.1108/rausp-04-20180008
Schmeiser, M. D., \& Seligman, J. S. (2013). Using the right yardstick: Assessing financial literacy measures by way of financial well-being. Journal of Consumer Affairs, 47(2), 243-262.

Tang, N., \& Baker, A. (2016). Self-esteem, financial knowledge and financial behavior. Journal of Economic Psychology, 54, 164-176.

Twibell, R. S., Siela, D., Riwitis, C., Wheatley, J., Riegle, T., Bousman, D., ... Hollars, R. (2008). Nurses' perceptions of their self-confidence and the benefits and risks of family presence during resuscitation. American Journal of Critical Care, 17(2), 101-111.

Van Rooij, M. C. J., Lusardi, A., \& Alessie, R. J. M. (2011). Financial literacy and retirement planning in the Netherlands. Journal of Economic Psychology, 32(4), 593-608.

Woodyard, A. S., Robb, C., Babiarz, P., \& Jung, J. (2017). Knowledge and practice: Implications for cash and credit management behaviors. Family and Consumer Sciences Research Journal, 45(3), 300-314.

Xia, T., Wang, Z., \& Li, K. (2014). Financial literacy overconfidence and stock market participation. Social Indicators Research, 119(3), 1233-1245. 